Tips om medisinsk litteratur, andre bøker, filmer og elektroniske medier som bør anmeldes, sendes redaksjonen@tidsskriftet.no

\section{Den første norske boken om kognitiv terapi ved psykose}

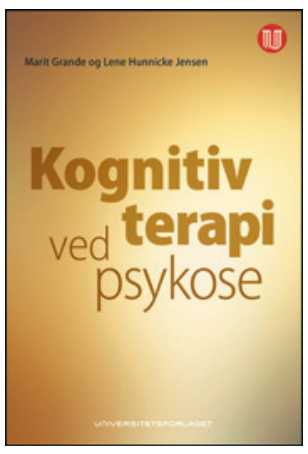

Marit Grande, Lene Hunnicke Jensen Kognitiv terapi ved psykose

213 s, tab, ill. Oslo: Universitetsforlaget, 2016 Pris NOK 369

ISBN 978-82-15-02365-6

Dette er en lettlest og praktisk rettet bok om kognitiv terapi ved psykoser. Forfatterne er erfarne kognitive terapeuter og har i mange år gitt helsepersonell undervisning og veiledning i metoden.

Den begynner med å gi en generell innføring i kognitiv terapi og kan leses uten spesielle forkunnskaper i kognitiv terapi. Senere tar den for seg forståelse og symptomer ved psykoselidelser. Stresssårbarhetsmodellen og nevrobiologiske forklaringsmodeller for psykose beskrives godt. I kapitlet om den kognitive forståelsesmodellen ved psykose og selve terapiprosessen omtales også det viktige arbeidet med å få til en god terapirelasjon, og det fortløpende arbeidet med å engasjere pasienten $\mathrm{i}$ behandlingen. Kun ett lite avsnitt omhandler utredning, her må en naturlig nok gå til andre kilder.

Kognitiv terapi ved henholdsvis vrangforestillinger, hallusinasjoner og negative symptomer omtales i egne kapitler. Her er teksten rikelig innbakt med kliniske vignetter som bidrar til å belyse behandlingsmetoden, med konkrete eksempler på intervensjoner og holdninger hos terapeuten for å fremme bedring, mestring og livskvalitet hos pasienten. Forfatterne er tydelige på at pasienter med psykoser er forskjellige og at metoden må tilpasses den enkelte.

Kognitiv terapi er anbefalt som ett av flere behandlingstiltak for pasienter med psykoselidelser. Metoden har vist positiv effekt på psykosesymptomer og funksjon, har få bivirkninger og er ofte ønsket av pasientene selv. De norske nasjonale retningslinjene for behandling av psykoselidelser anbefaler at alle som plages med psykosesymptomer $b ø r$ få tilbud om kognitiv terapi med individuelle forløp med en varighet på minst 15-20 samtaler, mens de engelske NICE-retningslinjene går lenger og anbefaler at alle som har en psykoselidelse skal få tilbud om kognitiv terapi.

I boken redegjøres kort for andre grunnpilarer i behandling av psykoselidelser, nemlig medikamentell behandling og psykoedukativt familiesamarbeid. Det presiseres at kognitiv terapi ikke er noe som kommer i stedet for andre behandlingstiltak, men i tillegg.

Det som kunne kommet tydeligere frem er begrensningene med kognitiv terapi ved psykose. Metoden har ingen sikker dokumentert effekt på negative symptomer og heller ikke ved tilbakefall av psykose. Det kunne videre vært ett tilskudd om boken også beskrev nyutviklete metoder basert på kognitiv terapi. Avatar therapy har for eksempel vist lovende resultater.

Utgivelsen kan anbefales for alle klinikere som kommer i kontakt med pasienter med psykoselidelser, og bør bli obligatorisk lesing for alle leger i spesialisering i psykiatri. Den kan bidra til å gjøre en dokumentert behandling mer tilgjengelig for pasienter med psykoselidelser ved at helsepersonell som arbeider med pasientgruppen utdanner seg og får veiledning i anvendelse av metoden.

\section{Terje Fladvad}

Spesialist i psykiatri, Fladvads psykiatripraksis Oslo

\section{Lettlest innføring i avhengighetspsykologi}

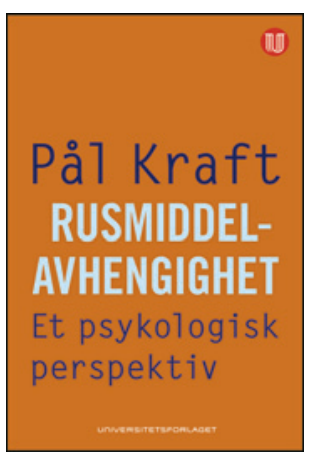

\author{
Pål Kraft
}

Rusmiddelavhengighet

Et psykologisk perspektiv. $232 \mathrm{~s}$.

Oslo: Universitetsforlaget, 2016.

Pris NOK 349

ISBN 978-82-15-02626-8

Legenes rolle i rusfeltet har utviklet seg betydelig det siste tiåret.

Rusomsorgen ble formelt en del av spesialisthelsetjenesten allerede i 2004, men først i de senere årene har spesialistutdanningen i rusog avhengighetsmedisin kunnet tilrettelegge for leger som ønsker en karriere innen behandling av rusproblematikk. Samtidig fortsetter rusfeltet å være tverrfaglig organisert med en klar biopsykososial tilnærming.

Psykologisk forståelse og behandling av avhengighet har hele tiden stått sentralt i psykologutdanningen, og den har lenge tilbudt et spesialiseringsløp innen avhengighet. Denne utgivelsen er spesielt egnet for leger som ønsker en oppdatert innføring i ruslidelsenes psykologi, men er også nyttig lesing for alle andre som vil forstå avhengighet bedre.

Forfatteren oppsummerer det psykologiske perspektivet på rusmiddelavhengighet grundig ved å beskrive de ulike elementene av mistilpasning som utgjør avhengighetsatferd. Forfatteren beskriver sentrale psykologiske modeller som forklarer tilsynelatende paradoksal atferd, nemlig daglig inntak av rusmidler til tross for innsikt i de helseskadelige konsekvenser. Leseren blir minnet på at rusavhengighet dreier seg om alvorlige, langvarige lidelser som ofte har dårlige prognose. Samtidig kommuniseres det implisitt at en forenklet moralistisk forklaring av atferden som preger mennesker med avhengighet er avleggs. Utviklingen av rusmiddelavhengighet kan heller forklares med motivasjonelle forstyrrelser knyttet til rusmiddelutløst velbehag (eller demping av ubehag), dysfunksjonelle beslutningsprosesser og redusert evne til impulskontroll som oppstår over tid.

Forfatteren går grundig gjennom atferdsmønstre og selvregulering ved motivasjon, vanedanning, belønning og svekket kontroll. Det gis en oversiktlig oppsummering av rusmidlenes evne til å forstyrre belønningssystemet, godt begrunnet med sentrale referanser innen nevrovitenskap. Fire teoretiske kapitler rammes inn av en kort innledning og en innføring i diagnostikk av ruslidelser $i$ begynnelsen, og er fulgt av to klinisk rettede kapitler om sårbarhet, komorbiditet og behandling før det hele avsluttes med ruspolitiske betraktninger og en kort oppsummering.

De nevrobiologiske beskrivelsene av avhengighet, som forstyrrelse i forventning, motivasjon og et overfølsomt belønningssystem, er bokens mest oppdaterte, og for leger med kunnskap fra rusfeltet er disse modellene nok de mest kjente. Således gir kapitlene om mer grunnleggende psykologisk forståelse av læring, automatisering, vanedanning og selvregulering et godt supplement.

\section{Philipp Lobmaier}

Lege i spesialisering, ph.d., Senter for Rus- og Avhengighetsforskning (SERAF) Universitetet i Oslo 